Volume 15 Nomor 2, Desember 2019

\title{
Pengaruh Penerapan Standar Operasional Prosedur terhadap Efektifitas Pelayanan Keuangan di IAIN Sultan Amai Gorontalo
}

\author{
Sulam \\ Mujahid Domopoli \\ Asna Usman Dilo \\ IAIN Sultan Amai Gorontalo \\ E-mail: sulam141174@gmail.com
}

\begin{abstract}
Standard Operating Procedure (SOP) is an instrument that contains the processes and procedures of an activity based on a standard that has been standardized. This study determined the effect of the application of standard operating procedures on the effectiveness of financial services, especially at IAIN Sultan Amai Gorontalo. This research used a quantitative approach, with data collection methods through tests, questionnaires, and interviews. Data analysis was conducted to test the effect of the tested variables, namely the application of SOP (X) to IAIN Sultan Amai Gorontalo financial services (Y). The results showed that the application of SOP conducted at IAIN Sultan Amai Gorontalo influenced financial services at IAIN Sultan Amai Gorontalo. In its implementation, the SOP implemented at IAIN Sultan Amai Gorontalo has made financial services easier and more directed.
\end{abstract}

Keywords: Standard operating procedures, effectiveness of financial services, IAIN Sultan Amai Gorontalo

\section{Pendahuluan}

Salah satu faktor penting dalam sebuah organisasi adalah tersedianya sumber daya manusia. Sumber daya manusia yang tinggi memiliki peran penting dalam memajukan suatu negara, perusahaan, maupun organisasi. Tanpa sumber daya manusia yang tinggi, suatu negara, perusahaan, maupun organisasi akan sulit berkembang. Sumber daya manusia yang dimaksud adalah orang-orang yang memberikan tenaga, pikiran, bakat, kreativitas dan usahanya pada negara, perusahaan, maupun organisasi. Setiap instansi selalu berupaya untuk mendapatkan karyawan/pegawai yang dapat memberikan suatu capaian ataupun target yang sudah ditetapkan sebelumnya. Selain target yang dicapai, instansi yang baik juga adalah yang dapat meningkatkan pelayanan yang efektif dan efisien terhadap para penggunanya.

Efektivitas merupakan unsur pokok aktivitas organisasi dalam mencapai tujuan atau sasaran yang telah ditentukan sebelumnya. Dari aspek kecepatan waktu, maka efektivitas tercapainya berbagai sasaran yang telah ditentukan tepat pada waktunya dengan 
menggunakan sumber-sumber tertentu yang disediakan untuk melaksanakan berbagai kegiatan dalam program yang telah disusun sebelumnya. Komarudin (1994) menyatakan bahwa efektivitas adalah suatu keadaan dalam mencapai tujuan.

Manajemen yang efektif perlu disertai dengan manajemen yang efisien. Tercapainya, tujuan mungkin hanya dapat dilakukan dengan penghamburan dana, oleh karena itu manajemen tidak boleh hanya diukur dengan efektivitas tetapi juga diperlukan efisiensi. Efektif selain ditempuh dengan tercapainya suatu tujuan dan sasaran, juga bisa melalui penghasilan sejumlah barang atau jasa dengan mutu tertentu dan tepat waktu. Hal tersebut sesuai dengan apa yang dikemukakan oleh Siagian (2003), yakni efektivitas adalah pemanfaatan berbagai sumber daya, dana, sarana dan prasarana, dalam jumlah tertentu yang secara sadar ditetapkan sebelumnya untuk menghasilkan sejumlah barang atau jasa dengan mutu tertentu, tepat pada waktunya.

Sementara itu, Pelayanan publik merupakan salah satu tugas penting yang tidak dapat diabaikan oleh pemerintah sebab jika komponen pelayanan terjadi stagnasi maka hampir dipastikan semua sektor akan berdampak kemacetan. Dengan adanya kualitas pelayanan yang baik maka dapat menimbulkan rasa puas dan sikap positif dari masyarakat. Hal ini dikarenakan kepuasan merupakan perasaan senang atau kekecewaan seseorang yang berasal dari perbandingan antara kesannya terhadap kinerja seseorang dan harapannya. Perbaikan kinerja birokrasi pelayanan publik akan mempunyai implikasi luas terutama dalam tingkat kepercayaan masyarakat kepada pemerintah sedangkan kurang baiknya kinerja birokrasi selama ini menjadi salah satu faktor penting yang mendorong munculnya krisis kepercayaan masyarakat kepada pemerintah.

Permasalahan yang dihadapi saat ini oleh masyarakat dalam pelayanan yang diberikan oleh aparatur pemerintah seringkali cenderung rumit seperti: a) Tata cara pelayanan, b) Rendahnya pendidikan aparat, c) Standar Operasional Prosedur tidak dijalankan, hal ini sangat berpengaruh terhadap kualitas pelayanan (Ratminto \& Winarsih, 2014). Selain menciptakan pelayanan yang efektif, setiap instansi tidak bisa lepas dari menyiapkan instrument. Instrument atau perangkat yang sangat penting dan harus ada pada setiap Instansi adalah Standar Operasional Prosedur (SOP).

Perumusan SOP menjadi relevan karena sebagai tolok ukur dalam menilai efektivitas dan efisiensi kinerja instansi dalam melaksanakan program kerjanya. Secara konseptual prosedur diartikan sebagai langkah-langkah sejumlah instruksi logis untuk menuju pada suatu proses yang dikehendaki. Proses yang dikehendaki tersebut berupa pengguna-pengguna sistem 
proses kerja dalam bentuk aktivitas, aliran data, dan aliran kerja. Standar operasional prosedur adalah proses standar langkah-langkah sejumlah instruksi logis yang harus dilakukan berupa aktivitas, aliran data, dan aliran kerja.

SOP ditinjau dari fungsinya, yakni membentuk sistem kerja dan aliran kerja yang teratur, sistematis, dan dapat dipertanggungjawabkan, menggambarkan bagaimana tujuan pekerjaan dilaksanakan sesuai dengan kebijakan dan peraturan yang berlaku, menjelaskan bagaimana proses pelaksanaan kegiatan berlangsung, sebagai sarana tata urutan dari pelaksanaan dan pengadministrasian pekerjaan harian sebagaimana metode yang ditetapkan, menjamin konsistensi dan proses kerja yang sistematik, dan menetapkan hubungan timbal balik antar Satuan Kerja (KMA, 2010). Secara umum, SOP merupakan gambaran langkahlangkah kerja (sistem, mekanisme dan tata kerja internal) yang diperlukan dalam pelaksanaan suatu tugas untuk mencapai tujuan. SOP sebagai suatu dokumen/instrumen memuat tentang proses dan prosedur suatu kegiatan yang bersifat efektif dan efisisen berdasarkan suatu standar yang sudah baku. Pengembangan instrumen manajemen tersebut dimaksudkan untuk memastikan bahwa proses pelayanan di seluruh unit kerja instansi dapat terkendali dan dapat berjalan sesuai dengan ketentuan yang berlaku.

IAIN Sultan Amai Gorontalo sejak awal telah merancang, membuat, dan menerapkan SOP dalam sistem pelayanan kegiatan, namun kenyataannya proses kegiatan yang jalan masih kurang maksimal. Masalah nyata proses pelayanan keuangan, terutama pengurusan kuangan kegiatan dirasakan masih kurang efektif. Eksistensi efektivitas pelayanan keuangan ini diasumsikan karena pengaruh tingkat sumber daya manuasi pengelolanya kurang sesuai dengan kebutuhan dan belum optimalnya penarapan standar operasional prosedur yang ada. Penelitian ini ingin mengetahui pengaruh penerapan standar operasional prosedur terhadap efektivitas pelayanan keuangan dengan, khususnya di IAIN Sultan Amai Gorontalo.

\section{Tinjauan Pustaka}

\subsection{Hakikat Standar Operasional Prosedur}

Standard Operasional Prosedur (SOP) adalah proses standar langkah-langkah sejumlah instruksi logis yang harus dilakukan berupa aktivitas, aliran data, dan aliran kerja yang teratur, sistematis, dan dapat dipertanggung-jawabkan; menggambarkan bagaimana tujuan pekerjaan dilaksanakan sesuai dengan kebijakan dan peraturan yang berlaku; menjelaskan bagaimana proses pelaksanaan kegiatan berlangsung; sebagai sarana tata urutan dari pelaksanaan dan pengadministrasian pekerjaan harian sebagaimana metode 
yang ditetapkan; menjamin konsistensi dan proses kerja yang sistematik; dan menetapkan hubungan timbal balik antar Satuan Kerja (Tjiptono, 2010).

Menurut Peraturan Menteri Negara Pemberdayaan Aparatur Negara dan Reformasi Birokrasi Nomor 35 Tahun 2012 tentang Pedoman Penyusunan Standar Operational Prosedur (SOP) Administrasi Pemerintahan, Standar Operasioan Prosedur (SOP) adalah serangkaian instruksi tertulis yang dibakukan mengenai berbagai proses penyelenggaraan administrasi pemerintahan, bagaimana dan kapan harus dilakukan, di mana dan oleh siapa dilakukan. Lebih lanjut dikatakan di dalam peraturan tersebut bahwa manfaat Standar Operasional Prosedur dalam lingkup penyelenggaraan administrasi pemerintahan meliputih: a) Sebagai standarisasi cara yang dilakukan pegawai dalam menyelesaikan pekerjaan yang menjadi tugasnya; b) Mengurangi tingkat kesalahan dan kelalaian yang mungkin dilakukan oleh seorang pegawai dalam melaksanakan tugas; c) Meningkatkan efisiensi dan efektivitas pelaksanaan tugas dan tanggungjawab individual pegawai dan organisasi secara keseluruhan; d) Membantu pegawai menjadi lebih mandiri dan tidak tergantung pada intervensi manajemen, sehlngga akan mengurangl keterlibatan pimpinan dalam pelaksanaan proses sehari-hari; e) Meningkatkan akuntabilitas pelaksanaan tugas; f) Menciptakan ukuran standar kinerja yang akan memberikan pegawai cara konkrit untuk memperbaiki kinerja serta membantu mengevaluasi usaha yang telah dilakukan; g) Memastikan pelaksanaan tugas penyelenggaraan pemerintahan dapat berlangsung dalam berbagai situasi; h) Menjamin konsistensi pelayanan kepada masyarakat, baik dari sisi mutu, waktu dan prosedur; i) Memberikan informasi mengenai kualifikasi kompetensi yang harus dikuasai oleh pegawai dalam melaksanakan tugasnya; j) Memberikan informasi bagi upaya peningkatan kompetensi pegawai; k) Memberikan informasi mengenai beban tugas yang dipikul oleh seorang pegawai dalam melaksanakan tugasnya; 1) Sebagai instrumen yang dapat melindungi pegawai dari kemungkinan tuntutan hukum karena tuduhan melakukan penyimpangan; m) Menghindari tumpang tindih pelaksanaan tugas; n) Membantu penelusuran terhadap kesalahan-kesalahan prosedural dalam memberikan pelayanan; dan o) Membantu memberikan informasi yang diperlukan dalam penyu-sunan standar pelayanan, sehingga sekaligus dapat memberikan informasi bagi kinerja pelayanan.

\subsection{Efektifitas Pelayanan Keuangan}

Handoko (1997) berpendapat efektifitas adalah kemampuan untuk memilih tujuan yang tepat atau peralatan yang untuk mencapai tujuan yang telah ditetapkan. Gie (1988) 
berpendapat bahwa efektivitas merupakan keadaan yang mengandung pengertian mengenai terjadinya suatu efek atau akibat yang dikehendaki, maka perbuatan itu dikatakan efektif kalau menimbulkan akibat atau mencapai maksud sebagaimana yang dikehendaki.

Lubis dan Husain (1987) mengemukakan bahwa terdapat beberapa pendekatan dalam mengukur efektifitas organisasi, yakni 1) Pendekatan sasaran (goals approach), dimana pusat perhatian pada output adalah mengukur keberhasilan organisasi untuk mencapai hasil (output) yang sesuai dengan rencana; 2) Pendekatan sumber (recourse approach) yakni mengukur efektivitas dari input. Pendekatan ini mengutamakan adanya keberhasilan organisasi untuk memperoleh SDM, baik fisik maupun nonfisik yang sesuai dengan kebutuhan organisasi; 3) Pendekatan proses (process approach) adalah untuk melihat sejauh mana efektifitas pelaksanaan program dari semua kegiatan proses internal atau mekanisme organisasi; dan 4) Pendekatan integratife (integrative approach) yakni pendekatan gabungan yang mencakup input, proses dan output.

Selanjutnya Siagian (2008) mendefinisikan bahwa efektivitas adalah memanfaatkan sumber daya, sarana dan prasarana dalam jumlah tertentu yang secara sadar ditetapkan sebelumnya untuk menghasilkan sejumlah barang atau jasa kegiatan yang dijalankannya. Jadi efektivitas menunjukkan keberhasilan dari segi tercapai tidaknya sasaran yang telah ditetapkan, jika hasil kegiatan semakin mendekati sasaran berarti makin tinggi efektivitasnya. Dengan demikian pada dasarnya efektivitas adalah tingkat pencapaian tujuan atau sasaran organisasional sesuai yang ditetapkan.

Efektivitas kerja organisasi sangat tergantung dari efektivitas kerja dari orang-orang yang bekerja di dalamnya. Sangat sulit untuk mengukur efektivitas kerja, karena penilaiannya sangat subjektif dan sangat tergantung pada orang yang menerima pelayanan tersebut. Kesukarannya terletak pada penarikan generalisasi yang akhirnya berlaku umum dan dapat diterima oleh setiap orang. Ada beberapa kriteria yang dapat digunakan untuk mengukur efektivitas kerja dari organisasi yang memberikan pelayanan, yakni (Siagian, 2008): 1) Faktor waktu. Faktor waktu di sini maksudnya adalah ketepatan waktu dan kecepatan waktu dari pelayanan yang diberikan oleh pemberi pelayanan. Hanya saja penggunaan ukuran tentang tepat tidaknya atau cepat tidaknya pelayanan yang diberikan berbeda dari satu orang ke orang lain. Terlepas dari penilaian subjektif yang demikian, yang jelas faktor waktu dapat dijadikan sebagai salah satu ukuran efektivitas kerja. 2) Faktor Kecermatan. Faktor kecermatan dapat dijadikan ukuran untuk menilai tingkat efektivitas kerja organisasi yang memberikan pelayanan. Pelanggan akan cenderung memberikan nilai yang tidak terlalu tinggi kepada 
pemberi pelayanan, apabila tejadi banyak kesalahan dalam proses pelayanan, meskipun diberikan dalam waktu yang singkat. 3) Faktor Gaya Pemberian Pelayanan. Gaya pemberian pelayanan merupakan salah suatu ukuran lain yang dapat dan biasa digunakan dalam mengukur efektifitas kerja. Yang dimaksud dengan gaya di sini adalah cara dan kebiasaan pemberi pelayanan dalam memberikan jasa kepada pelanggan. Bisa saja sipelanggan merasa tidak sesuai dengan gaya pelanggan yang diberikan oleh pemberi pelayanan.

Pelayanan pada dasarnya adalah cara melayani, membantu, menyikapi, mengurus, menyelesaikan keperluan kebutuhan seseorang atau sekelompok orang. Dan kegiatan pelayanan pada dasarnya menyangkut pemenuhan suatu hak. Seperti yang dilaksanakan pada instansi pemerintah di pusat, daerah, dan lingkungan Badan Usaha Milik Negara (BUMN), Badan Usaha Milik Daerah dalam bentuk barang dan jasa baik dalam rangka upaya pemenuhan kebutuhan masyarakat maupun dalam rangka pelaksanaan ketentuan perundangundangan. Sebagaimana yang dikemukakan oleh Kurniawan (2005), pelayanan publik adalah pemberian pelayanan (melayani) keperluan orang lain atau masyarakat yang mempunyai kepentingan pada organisasi itu sesuai dengan aturan pokok dan tata cara yang telah ditetapkan.

Pengelolaan keuangan negara dapat dikelompokkan: a) subbidang pengelolaan fiskal, b) subbidang pengelolaan moneter, dan c) subbidang pengelolaan kekayaan negara yang dipisahkan. Pengelolaan keuangan negara subbidang pengelolaan fiskal meliputi kebijakan dan kegiatan yang berkaitan dengan pengelolaan Anggaran Pendapatan dan Belanja Negara (APBN) mulai dari penetapan Arah dan Kebijakan Umum (AKU), penetapan strategi dan prioritas pengelolaan APBN, penyusunan anggaran oleh pemerintah, pengesahan anggaran oleh DPR, pelaksanaan anggaran, pengawasan anggaran, penyusunan perhitungan anggaran negara (PAN) sampai dengan pengesahan PAN menjadi undang-undang (UU No. 17 Tahun 2003). Pengelolaan keuangan negara subbidang pengelolaan moneter berkaitan dengan kebijakan dan pelaksanaan kegiatan sektor perbankan dan lalu lintas moneter baik dalam maupun luar negeri. Sementara itu, Pengelolaan keuangan negara subbidang kekayaan Negara yang dipisahkan berkaitan dengan kebijakan dan pelaksanaan kegiatan di sektor Badan Usaha Milik Negara/Daerah (BUMN/BUMD) yang orientasinya mencari keuntungan (profit motive).

\section{Metode Penelitian}

Penelitian ini menggunakan pendekatan kuantitatif. Penelitian kuantitaitf menggunakan 
alat pengumpulan data dalam bentuk test, angket, untuk pedoman wawancara atau observasi. Pengumpulan data dilakukan pada obyek tertentu baik berupa populasi maupun sampel, kemudian dilakukan analisis data guna menjawab rumusan masalah dan menguji hipotesis dengan teknik statistik tertentu. Pada dasarnya penelitian kuantitatif adalah untuk menjawab masalah. Proses penelitiannya bersifat linier, dengan langkah-langkah yang jelas.

Langkah-langkah yang dilakukan dalam penelitian ini adalah: a) Pengumpulan data yang diperoleh dengan menyebarkan angket sesuai dengan sampel yang telah ditentukan; b) Setelah dilakukan pengumpulan data tahap berikutnya adalah analisis pengaruh anatara variabel yang di uji, pengaruh Penerapan SOP (X) Terhadap Pelayanan Keuangan (Y) IAIN Sultan Amai Gorontalo.

Penelitian ini menggunakan paradigma sederhana dimana terdapat satu variabel independent dan satu variabel dependent dengan gambaran sebagai berikut (Sugiyono, 2014):

Gambar 1. Paradigma Sederhana

\begin{tabular}{|c|c|}
\hline X \\
Openarapan Standar \\
\end{tabular}$\longrightarrow \begin{gathered}\mathrm{Y} \\
\text { (Efektifitas Pelayanan } \\
\text { Keuangan) }\end{gathered}$

Penelitian ini mengambil lokasi di IAIN Sultan Amai Gorontalo tepatnya pada Bagian Perencanaan dan Keuangan. Penentuan lokasi ini, menimbang bahwa bagian perencanaan dan keuangan merupakan bagian yang sangat penting dan kompleks terutama dalam hal pelayanan keuangan. Di sisi lain, peneliti merupakan salah satu pelaku di bidang perencanaan dan keuangan, sehingga peneliti tertarik meneliti secara langsung kegiatan pelayanan keuangan di IAIN Sultan Amai Gorontalo.

Pengumpulan data dalam penelitian ini menggunakan angket. Alasan digunakannya angket sebagai pengumpul data karena angket mempunyai kedudukan yang tinggi dan memiliki kemampuan mengungkap potensi yang dimiliki responden serta dilengkapi petunjuk yang seragam bagi responden (Arikunto, 2013). Angket juga dapat mengambil data dalam jumlah relatif lebih banyak. Penggunaan teknik penggumpulan data adalah hal yang utama menunjang penelitian. Teknik pengumpulan data yang dipergunakan dengan menyebarkan angket dan observasi terstruktur (Sugiyono, 2014).

Pengukuran dalam penelitian menggunakan Skala Likert, yakni suatu skala 
psikometrik yang umum digunakan dalam angket, dan merupakan skala yang paling banyak digunakan dalam riset berupa survei. Nama skala ini diambil dari nama Rensis Likert, yang menerbitkan suatu laporan yang menjelaskan penggunaannya. Dimana skala likert termasuk dalam metode pengguruan data skala interval, suatu skala di mana objek/kategori dapat diurutkan berdasarkan suatu atribut tertentu, jarak/interval atara tiap objek dikategorikan sama (Siregar, 2013). Responden menentukan tingkat persetujuan mereka terhadap suatu pernyataan dengan memilih salah satu dari pilihan yang tersedia. Biasanya disediakan lima pilihan skala dengan format seperti:
a. Selalu (SL) $=5$
b. $\quad$ Sering (SR)
$=4$
c. Kadang-Kadang(KD)
$=3$
d. Jarang (JR)
$=2$
e. Tidak Pernah(TP).
$=1$

Adapun alasan penggunaan Skala Likert dalam penelitian ini adalah karena kelebihan dan keuntungan dalam penggunaannya sebagai berikut:

a) Skala likert dapat diubah dan dinterprestasikan dengan mudah.

b) Skala likert merupakan bentuk pengukuran yang sangat lazim dipkai.

c) Pengukuran summated rating adalah pengukuran oridinal.

d) Skala likert sama dengan bentuk pengukuran sikap lainnya seperti skala Thurstone dan skala Guttman

\section{Hasil Penelitian}

\subsection{Deskripsi Data Variabel X (Penerapan Standar Operasional Prosedur)}

Berdasarkan hasil pengumpulan data melalui penyebaran kuesioner kepada responden atas penerapan standar operasional prosedur (variabel X), pada umumnya menyatakan bahwa penerapan standar operasional prosedur yang cukup baik sehingga pelayanan sangat efektif dan efisien yang menghasilkan ketepatan kerja yang memuaskan konsumen atau penerima layanan. Pendistribusian frekuensi skor untuk data variabel x (penerapan standar operasional prosedur) dapat dilihat pada tabel berikut ini:

\section{Tabel IV}

Daftar Distribusi Frekuensi

\section{Variabel X (Penerapan Standar Operasional Prosedur)}




\begin{tabular}{|c|c|c|c|}
\hline No. & Kelas Interval & Frekuensi & $\begin{array}{c}\text { Frekuensi } \\
\text { Relatif }\end{array}$ \\
\hline 1. & $55-66$ & 1 & $1,41 \%$ \\
\hline 2. & $67-78$ & 1 & $1,41 \%$ \\
\hline 3. & $79-90$ & 8 & $11,27 \%$ \\
\hline 4 & $91-102$ & 9 & $12,68 \%$ \\
\hline 5 & $103-114$ & 27 & $38,03 \%$ \\
\hline 6 & $115-126$ & 16 & $22,54 \%$ \\
\hline 7 & $127-138$ & 9 & $12,68 \%$ \\
\hline \multicolumn{2}{|r|}{ JUMLAH } & 71 & \\
\hline
\end{tabular}

Berdasarkan Tabel distribusi frekuensi di atas, dapat terlihat bahwa 27 orang $(38,03 \%)$ kecenderungan menjawab "selalu" dan "sering" terhadap penerapan SOP di IAIN Sultan Amai Gorontalo, Total jawaban responden tersebut ada pada interval $103-114$. Melalui perhitungan manual yang ada pada lampiran 5 diperoleh nilai Median $(\mathrm{Me})=109,14$ dan Nilai Modus $(\mathrm{Mo})=109,32$.

Selanjutnya frekuensi distribusi pengamatan variabel $\mathrm{X}$ (Penerapan Standar Operasional Prosedur) dapat dilihat melalui histogram dibawah ini:

Gambar 1:

Histogram frekuensi pengamatan variabel X (Penerapan Standar Operasional Prosedur)

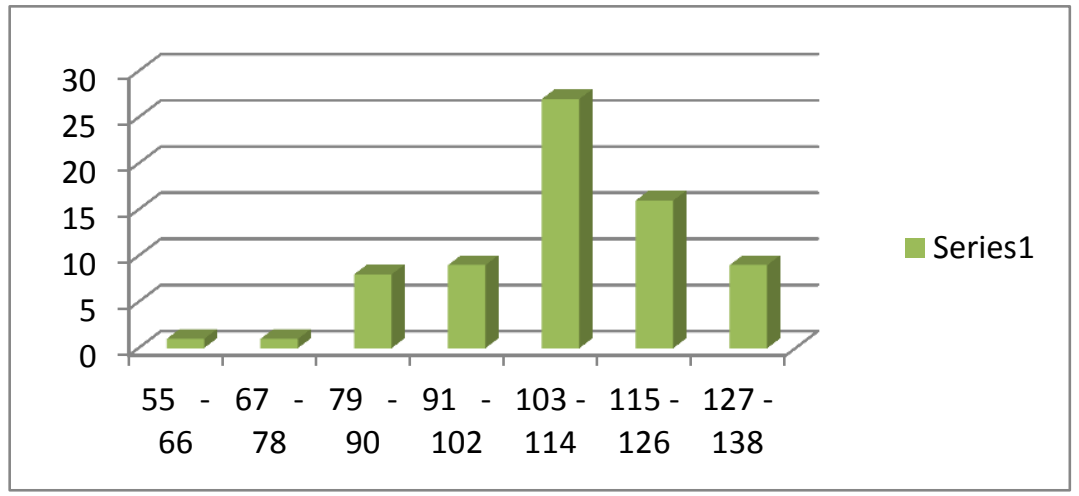

\subsection{Deskriptif Data Variabel Y (Pelayanan Keuangan)}

Penelitian ini yang menjadi variabel terikat (Y) adalah Pelayanan keuangan di lingkungan IAIN Sultan Amai Gorontalo. Untuk mengetahui pelayanan keuangan dengan 
melihat hasil penyebaran angket yang diberikan pada 71 responden. Hasil penyebaran angket dapat dilihat pada lampiran 4.

Berdasarkan data yang diperoleh, maka distribusi frekuensi variabel Y dapat dilihat pada tabel berikut ini:

\section{Tabel V \\ Daftar distribusi frekuensi \\ Variabel Y (Pelayanan Keuangan)}

\begin{tabular}{|c|c|c|}
\hline No & Kelas interval & Frekuensi \\
\hline 1 & $73-82$ & 5 \\
\hline 2 & $83-92$ & 3 \\
\hline 3 & $93-102$ & 4 \\
\hline 4 & $103-112$ & 23 \\
\hline 5 & $113-122$ & 21 \\
\hline 6 & $123-132$ & 13 \\
\hline 7 & $133-142$ & 2 \\
\hline \multicolumn{2}{|c|}{ JUMLAH } & 71 \\
\hline
\end{tabular}

Berdasarkan Tabel distribusi frekuensi di atas, terlihat bahwa 23 orang $(32,39 \%)$ kecenderungan responden menjawab "selalu" dan "sering" terhadap Pelayanan Keuangan di IAIN Sultan Amai Gorontalo, Total jawaban responden tersebut ada pada interval $103-112$. Melalui perhitungan manual yang ada pada lampiran 5 diperoleh Nilai Median $(\mathrm{Me})=111,5$ dan Nilai Modus $(\mathrm{Mo})=110,6$.

Untuk memberikan gambaran yang jelas tentang distribusi pengamatan variabel $\mathrm{Y}$ (Pelayanan Keuangan) dapat dilihat melalui histogram berikut ini: 
Gambar 1:

Histogram frekuensi pengamatan variabel Y (Pelayanan Keuangan)

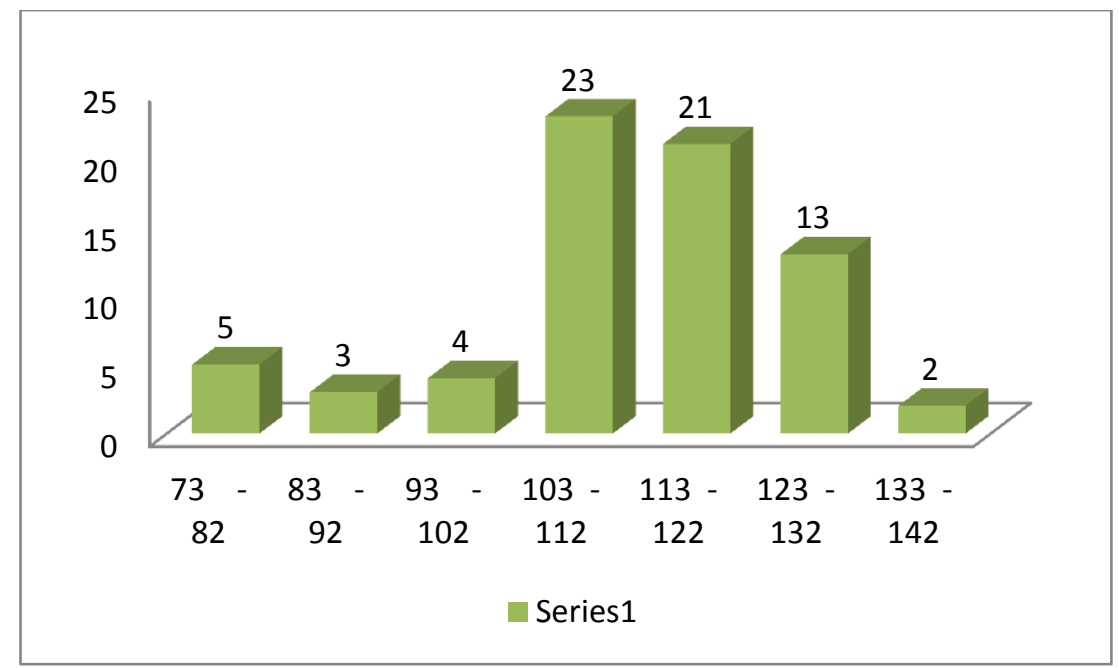

\subsection{Hasil Analisis Regresi Linear Sederhana}

Untuk output statistik deskriptif yang digunakan untuk melihat nilai mean dengan nilai standar deviasi:

\begin{tabular}{|c|c|r|r|}
\multicolumn{4}{|c}{ Descriptive Statistics } \\
\hline & Mean & $\begin{array}{c}\text { Std. } \\
\text { Deviation }\end{array}$ & $\mathrm{N}$ \\
\hline $\mathrm{Y}$ & $1.1125 \mathrm{E} 2$ & 14.27657 & 71 \\
$\mathrm{X}$ & $1.0896 \mathrm{E} 2$ & 15.38128 & 71 \\
\hline
\end{tabular}

Berdasarkan output tersebut dapat dilihat nilai mean variabel $\mathrm{X}$ atau penerapan Standar Operasional Prosedur dari 71 responden adalah 108,96. dengan standar deviasi 15,38128. Sedangkan nilai mean variabel Y atau Pelayanan Keuangan dari 71 responden adalah 111,25 dengan standar deviasi 14,27657.

Untuk hasil analisis antara variabel X (Penerapan Standar Operasional Prosedur) terhadap variabel Y (Pelayanan Keuangan) sebagai berikut: 


\begin{tabular}{|cc|r|r|}
\hline \multicolumn{1}{|c|}{ Correlations } \\
\hline & & $\mathrm{Y}$ & \multicolumn{1}{c|}{$\mathrm{X}$} \\
\hline Pearson Correlation & $\mathrm{Y}$ & 1.000 & .821 \\
& $\mathrm{X}$ & .821 & 1.000 \\
\hline Sig. (1-tailed) & $\mathrm{Y}$ &. & .000 \\
& $\mathrm{X}$ & .000 & \\
\hline $\mathrm{N}$ & $\mathrm{Y}$ & 71 & 71 \\
& $\mathrm{X}$ & 71 & 71 \\
\hline
\end{tabular}

Untuk korelasi antara variabel X (Penerapan Standar Operasional Prosedur) dengan variabel X (Pelayanan Keuangan) mempunyai arah korelasi positif yang artinya semakin tinggi penerapan standar operasional prosedur, maka pelayanan keuangan juga semakin tinggi. Demikian pula sebaliknya.

Berdasarkan hasil analisis korelasi yang diperoleh dengan menggunakan SPSS 16., diperoleh nilai korelasi 0,821 ( $\left.r_{\text {hitung }}=0,821\right)$, yang berarti bahwa tingkat Penerapan Standar Operasional Prosedur berkorelasi KUAT dengan Pelayanan Keuangan di IAIN Sultan Amai Gorontalo.

Untuk uji lineritas garis regresi digunakan untuk mengambil keputusan dalam memilih model regresi yang akan digunakan. Untuk uji lineritas garis regresi, hipotesis yang digunakan:

$\mathrm{H}_{0}: \rho=0$ ( Tidak terdapat pengaruh antara variabel $\mathrm{X}$ terhadap variabel $\mathrm{Y}$ )

$\mathrm{H}_{1}: \rho \neq 0$ ( terdapat pengaruh antara variabel $\mathrm{X}$ terhadap variabel $\mathrm{Y}$

\section{Coefficient}

\begin{tabular}{|c|c|c|c|c|c|}
\hline \multirow{2}{*}{ Model } & \multicolumn{2}{|c|}{$\begin{array}{l}\text { Unstandardized } \\
\text { Coefficients }\end{array}$} & $\begin{array}{c}\text { Standardized } \\
\text { Coefficients }\end{array}$ & \multirow[t]{2}{*}{$t$} & \multirow[t]{2}{*}{ Sig. } \\
\hline & B & Std. Error & Beta & & \\
\hline 1 (Constant) & 28.245 & 7.023 & & 4.022 & .000 \\
\hline$x$ & .762 & .064 & .821 & 11.936 & .000 \\
\hline
\end{tabular}

a. Dependent Variable: $Y$

Hasil analisis dengan menggunakan SPSS 16.0 diperoleh model regresi linear sebagai berikut:

$$
\mathrm{Y}=28,245+0,762 \mathrm{X}
$$


Nilai konstanta adalah 28,245 yang bernilai positif menunjukkan pengaruh positif variabel bebas atau variabel X (Penerapan Standar Operasional Prosedur). Bila variabel X naik atau berpengaruh dalam satu satuan jam kerja, maka variabel terikat dalam hal ini variabel Y (pelayanan keuangan) akan naik atau terpenuhi.

Pada kolom unstandardized coefficient, nilai konstan sebesar 28,245 dan nilai

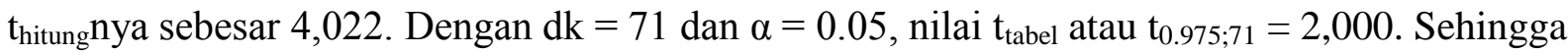
nilai $t_{\text {tabel }}<t_{\text {hitung }}$ yang berarti bahwa konstanta berpengaruh terhadap model regresi.

Pada kolom unstandardized coefficient, nilai variabel X (Penerapan Standar Operasional Prosedur) sebesar 0,762 dan nilai $t_{\text {hitung }}$ nya sebesar 11,936 , dengan $\mathrm{dk}=71$ dan $\alpha$ $=0.05$, nilai $t_{\text {tabel }}$ atau $t_{0.975 ; 71}=2,000$. Sehingga nilai $t_{\text {hitung }}>t_{\text {tabel }}$ yang berarti bahwa variabel $\mathrm{X}$ (Penerapan Standar Operasional Prosedur) berpengaruh terhadap model regresi.

Sedangkan nilai koefisien regresi variabel pelayanan keuangan (variabel X) terhadap variabel penerapan standar operasional prosedur (variabel Y) artinya jika pelayanan keuangan (variabel X) mengalami kenaikan satu satuan jam kerja, maka penerapan standar operasional prosedur (variabel Y) akan mengalami peningkatan sebesar 0,762 atau 76,2\%.

Berdasarkan uji $\mathrm{T}$ yang dilakukan dapat di tarik kesimpulan bahwa nilai $t_{\text {hitung }}$ sebesar 11,936, dengan $\mathrm{dk}=71$ dan $\alpha=0.05$, nilai $t_{\text {tabel }}$ atau $t_{0.975 ; 71}=2,000$. Sehingga nilai $t_{\text {hitung }}>t_{\text {tabel }}$ yang berarti bahwa hasil penelitian menolak $\mathrm{H}_{0}$ yang berarti bahwa terdapat pengaruh variabel X (Penerapan Standar Operasional Prosedur) terhadap variabel Y (Pelayanan Keuangan).

Standar deviasi yang diperoleh adalah 15,38128 sedangkan standar error yang diperoleh pada tabel coefficient sebesar 0,064 dari kedua angka tersebut dapat pula memberikan kesimpulan tentang model regresi yang diperoleh. Yaitu dengan melihat bahwa nilai standar error lebih kecil dari standar deviasi $(0.064<15,38128)$

Untuk menentukan kelinearan garis regresi dapat ditentukan dengan melihat nilai $\mathrm{F}$ dan Sig. pada tabel anova. Tabel anova hasil analisis SPSS sebagai berikut:

ANOVA $^{\mathrm{D}}$

\begin{tabular}{|c|c|c|c|c|c|c|}
\hline & Model & $\begin{array}{l}\text { Sum of } \\
\text { Squares }\end{array}$ & df & $\begin{array}{c}\text { Mean } \\
\text { Square }\end{array}$ & $F$ & Sig. \\
\hline \multirow[t]{3}{*}{1} & Regression & 9611.972 & 1 & 9611.972 & 142.462 & $.000^{a}$ \\
\hline & Residual & 4655.465 & 69 & 67.471 & & \\
\hline & Total & 14267.437 & 70 & & & \\
\hline
\end{tabular}

a. Predictors: (Constant), $X$

b. Dependent Variable: $Y$ 
Pada tabel ANOVA terdapat kolom untuk nilai $\mathrm{F}$ dan pada kolom Sig. Jika kita menggunakan nilai $\mathrm{F}$ berarti kita juga harus mencari terlebih dahulu nilai $F_{\text {tabel }}$ nya sehingga analisis ini akan lebih mudah menggunakan nilai Sig. Kriteria yang digunakan dalam pengujian ini adalah jika nilai Sig. Lebih dari atau sama dengan nilai alpha $(\alpha)$ yang telah ditentukan maka $\mathrm{H}_{0}$ diterima yang artinya persamaan garis regresi tidak linear dan jika nilai Sig. kurang dari nilai alpha maka $\mathrm{H}_{0}$ ditolak yang artinya persamaan garis regresi linear.

Pada tabel ANOVA yang telah diperoleh dengan menggunakan SPSS 16.0 dapat dilihat nilai Sig. sebesar 0.00. Nilai Sig. 0.00 ini kurang dari nilai $\alpha$ yaitu 0.05 yang artinya bahwa kita menolak $\mathrm{H}_{0}$ yang berarti bahwa persamaan garis regresinya linear.

Untuk uji Normalitas menggunakan regresi linear dengan melihat grafik (Charts). Dari data yang digunakan peneliti diperoleh chart sebagai berikut:

Normal P-P Plot of Regression Standardized Residual

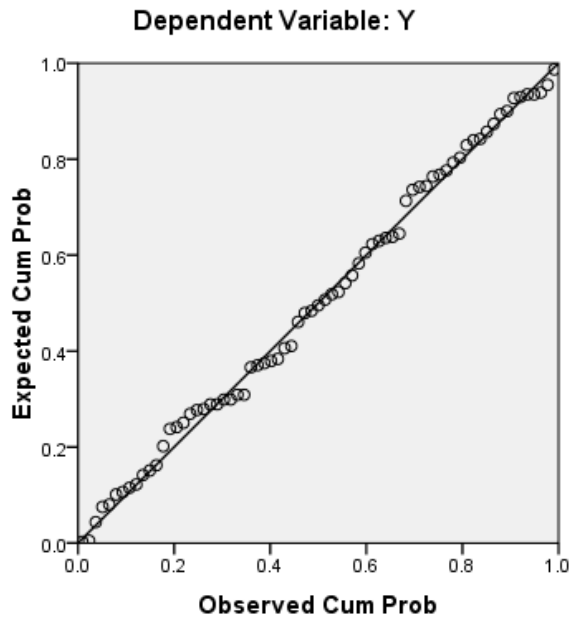

Pada chart terlihat bahwa data menyebar di sekitar garis diagonal dan mengikuti arah garis histograf menuju pola distribusi normal, maka regresi memenuhi asumsi normal.

Sedangkan untuk melihat seberapa besar kontribusi variabel independent yaitu variabel X (Penerapan Standar Operasional) terhadap variabel dependent yaitu variabel Y (Pelayanan Keuangan) dengan melihat nilai $R$-Square pada Tabel berikut:

\begin{tabular}{|c|c|c|}
\hline \multicolumn{3}{|c|}{ Model Summary } \\
\hline Model & $\mathrm{R}$ & R Square \\
\hline 1 & $.821^{\mathrm{a}}$ & .674 \\
\hline
\end{tabular}


Pada tabel dapat dilihat nilai $R$-Squarenya adalah 0,674 yaitu hasil kuadrat dari koefisien korelasi $(0,821 \mathrm{X} 0,821=0,674)$ yang berarti bahwa pengaruh variabel $\mathrm{X}$ (Penerapan Standar Operasional Prosedur) terhadap variabel Y (Pelayanan Keuangan) sebesar $67,4 \%$ dan $32.6 \%$ dipengaruhi oleh faktor lainnya.

\section{Pembahasan}

Standar Operasioan Prosedur (SOP) adalah serangkaian instruksi tertulis yang dibakukan mengenai berbagai proses penyelenggaraan administrasi pemerintahan, bagaimana dan kapan harus dilakukan, di mana dan oleh siapa dilakukan (Permenpan No. 13 Tahun 2012).

Sesuai pengertian dari standar operasional prosedur di atas pada penelitian ini membahas tentang bagaimana peranan SOP terhadap pelayanan keuangan. Dari hasil penelitian diperoleh sebuah nilai korelasi yaitu 0,821. Berdasarkan nilai tersebut dapat memberikan informasi tentang penerapan SOP sangat erat hubungannya dengan pelayanan keuangan di IAIN Sultan Amai Gorontalo. Nilai korelasi ini juga dapat menerangkan bahwa jika semakin sering menerapkan SOP maka akan lebih baik lagi pelayanan keuangan di lingkungan IAIN Sultan Amai Gorontalo. Pelayanan keuangan di lingkungan IAIN Sultan Amai Gorontalo menggunakan Standar Operasional Pelayanan (SOP) agar lebih terarah pelayanan yang dilakukan terhadap konsumen atau pengguna layanan.

Kegiatan pelayanan keuangan yang dilakukan di IAIN Sultan Amai Gorontalo sesuai dengan tujuan Standar Operasional Prosedur, yaitu:

1. Memberikan kepastian dan keseragaman dalam proses pelaksanaan suatu tugas.

2. Menunjang kelancaran dalam proses pelaksanaan tugas dan kemudahan pengendalian.

3. Mempertegas tanggung jawab dalam pelaksanaan tugas bagi aparatur.

4. Meningkatkan daya guna dan hasil guna secara berkelanjutan dalam melaksanakan tugas umum pemerintahan.

5. Memberikan informasi mengenai pelaksanaan tugas yang dilakukan oleh aparatur pemerintah secara proporsional.

6. Memberikan kejelasan dan transparansi kepada masyarakat sebagai penerima layanan mengenai hak dan kewajibannya (Permenpan No. 13 Tahun 2012).

Selain tujuan standar operasional prosedur, bagian pelayanan keuangan juga menggunakan SOP sesuai dengan prinsip SOP itu sendiri. Adapun prinsip SOP secara umum sebagai berikut: 
a. Prinsip-prinsip Penyusunan SOP (Permenpan No. 13 Tahun 2012):

1) Kemudahan dan kejelasan. Prosedur-prosedur yang distandarkan harus dapat dengan mudah dimengerti dan diterapkan oleh semua pegawai bahkan seseorang sama sekali baru dalam tugas pelaksanaan tugasnya.

2) Efisiensi dan efektivitas. Prosedur-prosedur yang distandarkan harus merupakan prosedur yang paling efisien dan efektif dalam proses pelaksanaan tugas.

3) Keselarasan. Prosedur-prosedur yang distandarkan harus selaras dengan prosedurprosedur standar lain yang terkait.

4) Keterukuran. Standar kualitas (mutu) tertentu yang dapat diukur pencapaian keberhasilannya.

5) Dinamis. Prosedur-prosedur yang distandarkan harus dengan cepat dapat disesuaikan dengan kebutuhan peningkatan kualitas pelayanan yang berkembang dalam penyelenggaraan administrasi pemerintahan.

6) Berorientasi pada pengguna (mereka yang dilayani). Prosedur-prosedur yang distandarkan harus mempertimbangkan kebutuhan pengguna (customer's needs) sehingga dapat memberikan kepuasankepada pengguna.

7) Kepatuhan hukum. Prosedur-prosedur yang distandarkan harus memenuhi ketentuan dan peraturan-peraturan pemerintah yang berlaku.

8) Kepastian hukum. Prosedur-prosedur yang distandarkan harus ditetapkan oleh pimpinan sebagai sebuah produk hukum yang ditaati, dilaksanakan dan menjadi instrumen untuk melindungi pegawai dari kemungkinan tuntutan hokum (Permenpan No. 13 Tahun 2012).

b. Prinsip-prinsip Pelaksanaan SOP:

1) Konsisten. SOP harus dilaksanakan secara konsisten dari waktu ke waktu, oleh siapapun, dan dalam kondisi apapun oleh seluruh jajaran organisasi pemerintahan.

2) Komitmen. SOP harus dilaksanakan dengan komitmen penuh dari seluruh jajaran organisasi, dari level yang paling rendah dan tertinggi.

3) Perbaikan berkelanjutan. Pelaksanaan SOP harus terbuka terhadap penyempurnaan-penyempurnaan untuk memperoleh prosedur yang benar- benar efisien dan efektif.

4) Mengikat. SOP harus mengikat pelaksana dalam melaksanakan tugasnya sesuai dengan prosedur standar yang telah ditetapkan.

5) Seluruh unsur memiliki peran penting. Seluruh pegawai peran-peran tertentu 
dalam setiap prosedur yang distandarkan. Jika pegawai tertentu tidak melaksanakan perannya dengan baik, maka akan mengganggu keseluruhan proses, yang akhirnya juga berdampak pada proses penyelenggaraan pemerintahan.

6) Terdokumentasi dengan baik. Seluruh prosedur yang telah distandarkan harus didokumentasikan dengan baik, sehingga dapat selalu dijadikan referensi bagi setiap mereka yang memerlukan.

Berdasarkan tabel Coefficient pada hasil analisis regresi linear sederhana di atas nilai Konstanta sebesar 28,245 menyatakan jika tidak ada peningkatan pelayanan keuangan dari penerapan standar operasional prosedur maka nilai dari pelayanan keuangan adalah 28,245. Koefisien regresi sebesar 0,762 menyatakan jika setiap pemberi layananan menerapkan SOP, maka akan meningkatkan pelayanan keuangan sebesar 0,762.

Berdasarkan hasil penelitian yang telah dikemukakan bahwa penerapan SOP menunjukkan pengaruh yang signifikan terhadap pelayanan keuangan. Keberhasilan sebuah pelayanan akan tercapai apabila menerapkan SOP pada setiap pelayanan dalam hal ini pelayanan keuangan. Keberhasilan dalam sebuah pelayanan adalah keinginan yang ingin dicapai setiap pemberi layanan dalam setiap instansi.

Pelayanan secara umum diharapkan mengandung unsur-unsur berdasarkan sebagai berikut:

a. Kesederhanaan: pelayanan umum harus mudah, cepat, lancar, tidak berbelit-belit, mudah dipahami, dan mudah dilaksanakan.

b. Kejelasan dan kepastian: dalam hal proses pelayanan, unit pejabat yang bertanggungjawab, hak dan kewajiban petugas dalam maupun pelayanan dan pejabat atau petugas yang menangani keluhan dari masyarakat.

c. Keamanan: proses dan hasil pelayanan harus aman dan nyaman, serta memberikan kepastian hukum.

d. Keterbukaan: segala sesuatu tentang proses pelayanan harus disampaikan secara terbuka kepada masyarakat diminta ataupun tidak.

e. Efesien: tidak perlu terjadi duplikasi persyaratan oleh beberapa pelayanan sekaligus.

f. Ekonomis: biaya pelayanan ditetapkan secara wajar dengan mempertimbangkan nilai layanan daya beli masyarakat dan peraturan perundangan lainnya.

g. Keadilan: pelayanan harus merata dalam hal jangkauan dan pemanfaatannya.

h. Ketetapan waktu: tidak perlu berlama-lama. 
Unsur-unsur pelayanan tersebut telah dilakukan di IAIN Sultan Amai Gorontalo, hal tersebut dapat dilihat dari hasil angket yang telah diisi oleh responden. Walau ada beberapa yang merasa tidak puas dengan layanan tersebut, tetapi akan menjadi perbaikan buat pelayanan di IAIN Sultan Amai Gorontalo. Dengan lebih mentaati SOP yang telah di standarkan maka akan lebih baik pula pelayanan.

Hasil penelitian memberikan informasi bahwa para pemberi layanan dalam hal ini pada pelayanan keuangan rata-rata menerapkan SOP dalam pelayanan, sehingga dapat melakukan pelayanan secara prima dengan menyelesaikan tepat waktu serta adanya kejelasan dalam pelayanan.

Hal tersebut dapat dilihat pada tabel $R$ Square yaitu sumbangan penerapan SOP yang diberikan para pemberi layanan sebesar $67,4 \%$, sisanya sebesar $32.6 \%$ pelayanan keuangan dipengaruhi oleh faktor-faktor lain. Dengan demikian berarti antara penerapan SOP dengan pelayanan keuangan memiliki hubungan yang kuat, sehingga berdasarkan hasil analisis di atas, hipotesis yang menunjukkan bahwa "Penerapan Standar Operasional Prosedur (SOP) mempunyai pengaruh besar terhadap pelayanan keuangan di IAIN Sultan Amai Gorontalo", "diterima". dapat diperoleh $\mathrm{t}_{\text {hitung }}=11,936$ dan $\mathrm{t}_{\text {tabel }}=2,000$, ini menunjukkan menolak $\mathrm{H}_{0}$. Dengan demikian berarti terdapat pengaruh penerapan standar operasional prosedur terhadap pelayanan keuangan di IAIN Sultan Amai Gorontalo.

Berdasarkan hasil analisis di atas dapat disimpulkan bahwa penerapan Standar Operasional Prosedur menunjukkan adanya pengaruh yang sangat besar terhadap pelayanan keuangan di IAIN Sultan Amai Gorontalo, dimana penerapan SOP tersebut dapat dilihat mulai dari awal penyusunannya sampai pada pelaksanaan SOP tersebut. Pelayanan keuangan yang diperoleh para penerima layanan dalam penelitian ini sangat baik, ini dilihat dari hasil angket pada lampiran 3 dan lampiran 4. Pelayan keuangan tersebut diperoleh dengan penerapan SOP yang telah distandarkan tersebut. Kesimpulan yang diambil dari sampel yang digunakan dapat digunakan untuk populasi yaitu pemberi layanan dalam hal ini pelayan keuangan di IAIN Sultan Amai Gorontalo, ini disebabkan oleh populasi yang bersifat homogen. Kehomogenan dapat dilihat pada tebel descriptif statistic.

\section{Simpulan}

Berdasarkan hasil penelitian pengaruh penerapan standar operasional prosedur terhadap pelayanan keuangan di IAIN Sultan Amai Gorontalo adalah: 
1. Persamaan regresi diperoleh $\mathrm{Y}=28,245+0,762 \mathrm{X}$, Nilai konstanta adalah 28,245 yang bernilai positif menunjukkan pengaruh positif variabel bebas atau variabel X (Penerapan Standar Operasional Prosedur). Bila variabel X naik atau berpengaruh dalam satu satuan jam kerja, maka variabel terikat dalam hal ini variabel Y (pelayanan keuangan) akan naik atau terpenuhi. Sedangkan nilai koefisien regresi variabel pelayanan keuangan (variabel X) terhadap variabel penerapan standar operasional prosedur (variabel Y) artinya jika pelayanan keuangan (variabel X) mengalami kenaikan satu satuan jam kerja, maka penerapan standar operasional prosedur (variabel Y) akan mengalami peningkatan sebesar 0,762 atau $76,2 \%$.

2. Berdasarkan uji t yang dilakukan dapat di tarik kesimpulan bahwa nilai $t_{\text {hitung }}$ sebesar 11,936, dengan $\mathrm{dk}=71$ dan $\alpha=0.05$, nilai $t_{\text {tabel }}$ atau $t_{0.975 ; 71}=2,000$. Sehingga nilai $t_{\text {hitung }}>t_{\text {tabel }}$ yang berarti bahwa hasil penelitian menolak $\mathrm{H}_{0}$ yang berarti bahwa terdapat pengaruh variabel X (Penerapan Standar Operasional Prosedur) terhadap variabel Y (Pelayanan Keuangan).

3. Hasil analisis menunjukkan bahwa penerapan standar operasional prosedur yang dilakukan di IAIN Sultan Amai Gorontalo mempengaruhi pelayanan keuangan di IAIN Sultan Amai Gorontalo. Dimana dalam pelaksanaannya Standar operasional prosedur yang diterapkan di IAIN Sultan Amai Gorontalo dimaksudkan untuk lebih mempermudah dan lebih terarah pada pelayanan keuangan.

\section{Daftar Pustaka}

Arikunto, S. 2013. Prosedur Penelitian: Suatu Pendekatan Praktik. Jakarta: Rineka Cipta.

Handoko, T. H. 1997. Manajemen dan Sumber Daya Manusia. Yogyakarta: Penerbit Liberty. KMA Nomor 168 Tahun 2010 tentang Pedoman Penyusunan Standar Operasional Prosedur di Lingkungan Kementerian Agama.

Komaruddin. 1994. Ensiklopedia Manajemen. Jakarta: Bumi Aksara

Kurniawan, A. 2005. Transformasi Pelayanan Publik. Yogyakarta: Pembaruan.

Lubis, H. S. B. dan M. Husaini, 1987. Teori Organisasi (Suatu Pendekatan Makro). Jakarta: Pusat Antar Universitas Ilmu-ilmu Sosial Universitas Indonesia.

Peraturan Menteri Negara Pemberdayaan Aparatur Negara dan Reformasi Birokrasi Nomor 35 Tahun 2012 tentang Pedoman Penyusunan Standar Operational Prosedur (SOP) Administrasi Pemerintahan.

Ratminto dan A. S. Winarsih. 2014. Manajemen Pelayanan: Yogyakarta: Pustaka Pelajar. 
Siagian, S. P. 2003. Teori dan Praktek Kepemimpinan. Jakarta: Rineka Cipta.

Siagian, S. P. 2008. Manajemen Sumber Daya Manusia. Cetakan 15. Jakarta: Bumi Aksara.

Siregar, S. 2013. Metode Penelitian Kuantitatif. Jakarta: PT Fajar Interpratama Mandiri.

Sugiyono. 2014. Metode Penelitian Pendidikan. Bandung: Alfabeta

Tjiptono, F. 2008. Service Management Mewujudkan Layanan Prima. Yogyakarta: CV. Andi Offset 